\title{
Human resources in tourism: Still waiting for change? - a 2015 reprise
}

\author{
Thomas Baum, University of Strathclyde, Glasgow, UK
}

\begin{abstract}
Seemingly intransigent human resource issues remain at the forefront of global tourism's challenges. Some of the key issues were identified in Baum's (2007) reflections on this topic. In light of the significant change that has impacted on tourism and employment in the intervening years, this conceptual paper provides an assessment of the current status of the issues that Baum identified in 2007 and identifies a range of emerging concerns that continue to shape the tourism workplace and workforce. The status of tourism work can be seen in terms of both continuity and change and the impact of these contrary forces is considered in reaching conclusions that highlight both the ongoing challenges for tourism and the evident progress that can be identified.
\end{abstract}

Key words: Tourism; Hospitality; Human resource management; Work; Employment

\section{Introduction}

In 2007, Tourism Management published a detailed assessment of the state of play with respect to human resources in tourism (Baum, 2007), with the somewhat pessimistic sub-title of "Still waiting for change", which focused on the notion that, in a world of increasing social, economic, political and technological churn, not least within tourism, some dimensions of people management and the role of human resources appeared to be frozen in time. The reputation of tourism as an employer remained, in this assessment, very mixed with excellent practice in some organisations located alongside widespread perceptions of poor pay, challenging working conditions and limited opportunities for growth and development, particularly for women and minorities. Baum's (2007) paper is by no means the only analyses of human resource themes pertaining to tourism that have been aired in recent years (see, for example, Lucas and Deery, 2004; Singh et al, 2007; Kusluvan et al, 2007; Davidson et al, 2011; and Tracey, 2014). The focus of most of these discussions is substantially organisational and managerialist. As a consequence, many of what might be seen as the substantive or structural issues relating to tourism employment are only considered in a fairly superficial manner, with limited attempt to really understand their causes and how they relate to wider social, cultural, economic or political considerations. Ladkin (2011:1152), in her own critique of the workplace environment within tourism, notes correctly that "It is no surprise that the management and economic perspectives dominate much of the research, but the complex societal and cultural factors cannot be ignored and the contribution that studying tourism labor can have on wider societal debates is significant". Of all the assessments of human resource issues in tourism 
that have been undertaken in recent years, Baum's (2007) iteration of this discourse is perhaps the most directly supportive of Ladkin in aiming to place tourism work and the management of the sector's employees in as wide a contextual environment as is possible and pertinent. Tourism and its workplaces have been subjected to the impact of sustained turbulence and change in macro social, economic, political and technological environmental terms since 2007. It is the aim of this paper, therefore, to provide an assessment that accommodates these changes and also takes a fresh but critical look at human resources in tourism through a 2015 lens.

The starting point from which Baum assessed the nature of change in tourism HRM in 2007, perhaps unfairly, was George Orwell's (1933) bleak questioning of the social significance of the tourism worker's life (in the proxy form of the plongeur) and Baum sought to demonstrate that aspects of work in tourism had, indeed, shifted little in the intervening seventy years. It is the contention of this paper that this comparator is somewhat limiting because the same analysis was also able to point to major enhancements in the tourism workplace and dramatic shifts within the way that organisations went about their people management business, driven by external change and guided by shifting values within society. In revisiting this theme some eight years later, therefore, it is important to acknowledge that implicit in Baum's 2007 assessment was the assumption that there could be some notion of real progress towards a state of maturity, fairness and mutual respect within people management in tourism. This assumption encapsulates, on the one hand, a broad commitment to the ILO's principles of decent work for the majority alongside boardroom recognition that the quality of the people in the workplace can make a real and positive difference to business outcomes. In picking up Baum's narrative on this topic after a number of years' reflection, the aim of this paper is to question whether aspirations of real progress towards this ideal were overly naive.

The genesis of this paper, following relatively hard on the heels of the 2007 discussion, is recognition of the fast pace of change over the intervening period and the desire to assess whether there has been evidence of discernable progress with respect to conditions in the tourism workplace in the intervening period. This focus on change relates to all dimensions of the external environment, insofar as they impact upon tourism, its workforce and the ways in which organisations marshal their human resources (Solnet et al, 2013). Macro-environmental change has been clearly evident across a broad spectrum of economic, political, socio-cultural and 
technological dimensions during the timeframe in question, a selection of which might include the gradual acceptance by most in the world community of climate change and the potential future scarcity of traditional energy resources; failure to halt the increasing gaps between the 'haves' and 'have nots' both within developed nations and between these countries and their poorer neighbours; gradual but patchy recovery from the global (read European/ North American) financial crisis; a rebalancing of global economies in favour of emerging economic powers, in part a response to crisis but reflecting more fundamental, underlying shifts; an escalation of political turbulence at a regional level in key flashpoints around the world; generational and technological change in consumer behaviour and the way in which we execute our choices; the power of social media and its impact on how we communicate with each other, with our brands, with our customers and within the workplace; and the rising power of lifestyle over more overt material career choices in developed economies. Each of these has direct consequences for tourism as a global industry, for work and the workplace and also for the management of people working within the myriad of businesses that go to make up the tourism sector.

Tourism's relationship to these and other developments can be characterized as a combination of both continuity and change. This, of course, is no original observation (see, for example, Richter, 2001 ) but, nonetheless, is a fair reflection of a tourism environment that has seen both turbulence and stability within a relatively short timeframe. On the one hand, it is clear that there has been continuity with respect to a number of key trends, including a drive towards greater sustainability in the use of finite and potentially harmful resources within travel and tourism; continued growth in both emerging outbound markets and new destinations; the impact of changing technologies on tourism distribution and consumer choice; and travel over greater distances and, paradoxically, for shorter periods of time, as outcomes of consumer choice and behaviour. Complementary to these more stable 'continuity' characteristics within tourism have been the impact of major world events on tourist choice and behaviour, whether natural disasters, the consequences of conflict or volatility in the economic and financial environment.

The purpose of this paper, then, is to provide an up-dated assessment of the key 'broad-brush' themes addressed by Baum in 2007, to establish whether conclusions drawn then remain valid today and to consider whether and in what respects the world of tourism HRM has changed in the intervening period. Baum (2007:1384) explained the purpose of his work in the following terms:

This paper seeks to make a partial assessment of the impact of external change on the human resource environment within tourism over the past 20 years, with particular focus on work and 
employment themes within the sector. In addressing a topic as broad as this, there is a real danger of uncritical generalisation within a highly heterogeneous sector such as tourism.

This paper aspires to build on Baum's work but it is also the aim of this discussion to progress the debate into a number of new and emerging areas, highlighting themes that have become more significant from both theoretical and applied perspectives. The caveat which was applicable to Baum's earlier work and has equal validity in this analysis today is that, inevitability, discussion in this paper is framed by selectivity and the dangers of generalizing about a business context which is so diverse. Potential themes for inclusion, then in 2007 and likewise, today, exceed in number those that can be addressed in any depth here. Therefore, there are inevitable gaps in the scope and depth of this analysis.

\section{A changing world, 2007-2014}

To claim that the world within which tourism employment is located has changed and continues to change at rapid pace is to state the obvious. Having said that, in many developed countries aspects of work in all sectors of the economy, not just tourism, exhibit major differences in 2014/15 from the way they were in 2006/07. The impact of such change, however, has been rather more muted in some of the world's poorest nations and for employees working in routine and marginalized occupations. In tourism, a wide range of influencers and drivers of workplace change can be identified and the most frequently cited in the literature (Edgell, 2014) are taken to include, inter alia, the factors that are summarised in Table 1.

\begin{tabular}{|l|l|}
\hline \multicolumn{1}{|c|}{ Influencers/ drivers of change in tourism } & \multicolumn{1}{|c|}{ Implications for work } \\
\hline $\begin{array}{l}\text { The nature of the tourism industry itself, with changing } \\
\text { patterns of travel with respect to both originating and } \\
\text { destination markets }\end{array}$ & $\begin{array}{l}\text { New skills and service demands - for example social } \\
\text { media-based marketing and the need for a wider portfolio } \\
\text { of language and cultural skills }\end{array}$ \\
\hline $\begin{array}{l}\text { The growing maturity of tourists as independent travellers, } \\
\text { with less dependence on pre-packaged programmes and } \\
\text { tours (Babu, 2014) }\end{array}$ & More bespoke/ individualised service delivery \\
\hline $\begin{array}{l}\text { Fluctuating economic conditions resulting in efforts to } \\
\text { drive down costs from key sectors in tourism, notably air } \\
\text { transport (CAPA, 2013), the emergence of retrenchment } \\
\text { strategies such as the 'staycation', a clear luxury - budget } \\
\text { polarization and an increasing focus on dynamic } \\
\text { packaging }\end{array}$ & $\begin{array}{l}\text { Elimination of key work areas, especially in tourism } \\
\text { intermediaries such as travel agents }\end{array}$ \\
\hline $\begin{array}{l}\text { The impact of social media on customers and their } \\
\text { decision making (Xiang et al, 2015) }\end{array}$ & $\begin{array}{l}\text { Pressure on workforce to adopt new communications } \\
\text { strategies }\end{array}$ \\
\hline $\begin{array}{l}\text { Changing tourism distribution systems, primarily through } \\
\text { evolving technologies (Mistilis et al, 2014) }\end{array}$ & $\begin{array}{l}\text { Altering or eliminating existing skills, creating new skills } \\
\text { and new jobs }\end{array}$ \\
\hline Growing awareness of environmental concerns within & Emergence of a demand for new range of 'green' skills \\
\hline
\end{tabular}




\section{Table 1: Impact of tourism change on work and the workplace}

These changes in Table 1 contribute significantly to subtle shifts in the skills and service demands placed on the workforce in tourism and, in turn, have implications for formative and in-service education and training programmes and providers and well as for the more general management of tourism workers.

The corollary of change within tourism that impacts upon employment is that the world of work, in turn, has constantly evolved in response to economic, political, socio-cultural and technological factors and key trends among these shifts likewise shape tourism and its capacity to offer various products and services. Key employment changes, which relate to the world of work, are summarised in Table 2.

\begin{tabular}{|c|c|}
\hline External environmental change & Impact on work \\
\hline $\begin{array}{l}\text { Sustained high levels of unemployment in some } \\
\text { developed countries, post } 2008 \text { (Gialis and Leontidou, } \\
\text { 2014) }\end{array}$ & $\begin{array}{l}\text { Strengthened hand of employers in the labour market with } \\
\text { impacts on recruitment, work conditions and benefits }\end{array}$ \\
\hline $\begin{array}{l}\text { Impact of the Global Financial Crisis on the professional } \\
\text { role of HRM within organisations - "For human resource } \\
\text { management (HRM), the global crisis represents an } \\
\text { external shock-wave that changes the parameters within } \\
\text { which HR professionals at all levels operate" (Zagelmeyer } \\
\text { and Gollan, 2012:3287) }\end{array}$ & $\begin{array}{l}\text { Reduced influence of HRM on strategic decision making } \\
\text { in organisations }\end{array}$ \\
\hline $\begin{array}{l}\text { A rise in under-employment (Cooper, 2014), with a } \\
\text { significant number of new entrants over-qualified for the } \\
\text { work available to them }\end{array}$ & $\begin{array}{l}\text { Increasing use of part-time and other reduced hours } \\
\text { contracts in the UK among other countries (Brinkley, } \\
\text { 2013); staff over-qualified for roles available to them }\end{array}$ \\
\hline $\begin{array}{l}\text { Continued weakening of organised labour across } \\
\text { developed country economies (Addison, 2014) }\end{array}$ & $\begin{array}{l}\text { Rise of employers that do not recognise trade unions - for } \\
\text { example, low cost airlines }\end{array}$ \\
\hline $\begin{array}{l}\text { Growth of new business models, notably through } \\
\text { outsourcing, both locally and on a global scale (Willcocks, } \\
\text { 2011) }\end{array}$ & $\begin{array}{l}\text { Removal of key roles (front and back office) from direct } \\
\text { employment by branded tourism companies (airlines, } \\
\text { hotels); off-shoring of selected back-office functions }\end{array}$ \\
\hline $\begin{array}{l}\text { Continued deskilling of key work areas, combined with } \\
\text { technology substitution for selected work areas (Falcioğlu, } \\
\text { 2014) }\end{array}$ & $\begin{array}{l}\text { Reduced demand for employees with traditional skills } \\
\text { training }\end{array}$ \\
\hline $\begin{array}{l}\text { A changing balance of power between employer and } \\
\text { employee - the increasing dominance of managerial/ } \\
\text { organisational objectives over individual employee } \\
\text { outcomes and aspirations (Clegg, 2014) }\end{array}$ & $\begin{array}{l}\text { Individual/ personal needs subjugated to organisational } \\
\text { priorities }\end{array}$ \\
\hline $\begin{array}{l}\text { Aspirations for greater balance between work and } \\
\text { personal life among employees (Haar et al, 2014) }\end{array}$ & $\begin{array}{l}\text { Conflict between employer rhetoric and reality (Solnet et } \\
\text { al, 2013) }\end{array}$ \\
\hline $\begin{array}{l}\text { In developing countries, rapidly growing levels of youth } \\
\text { unemployment in countries such as Egypt and Iran } \\
\text { (Pastore, 2014) }\end{array}$ & $\begin{array}{l}\text { Challenge for tourism to create employment opportunities } \\
\text { for increasing numbers }\end{array}$ \\
\hline
\end{tabular}

Table 2: External change and their impact on the workplace 
Many of these workplace change drivers are at the heart of the emergent forms of work that are replacing established practice or are based on new workplace employment relations. As an example, in this context, is the increasing dependence on volunteerism or unpaid work in tourismrelated areas such as events and heritage/ culture as well as in the proliferation of unpaid internships and 'starter' jobs (Burns, 2014). The contemporary politicization of such work models, whether genuine volunteering or 'forced' upon participants, is represented by UK Prime Minister David Cameron's "Big Society", described by Kisby (2010) as a high point in social conservatism which sits alongside along-side philanthropy as desired and desirable behavioral attributes in a modern society. In employment terms, using volunteers can also be a direct means by which commercial enterprises seek to reduce their costs and, possibly, increase profits for their stakeholders. Ockenden et al (2012:157), however, also sound a cautionary note when they argue that "Perhaps too much has been placed at the door of volunteering in recent years. Volunteering has the potential to change lives and frequently does, but it is not a panacea for all of society's ills".

It is clear that qualitative aspects of tourism work are changing but tourism employment is also growing in scale. Estimates of the scale of tourism employment vary but suggest that, globally, it is rising in the order of $2.4 \%$ per annum and will constitute approximately $3.4 \%$ of direct employment and $10.2 \%$ of total employment by 2014 (WTTC, 2014). Likewise, in the 57 countries of the Organisation of Islamic Cooperation (COMCEC, 2014), total tourism employment grew by $28 \%$ between 2001 and 2013 from an estimated 11.2 million to 14.3 million. In the UK, Payne and White (2014:1) report that the numbers working in tourism "increased at nearly double the rate of the rest of the UK labour market between 2009 and 2013 (5.4\% increase, rising 143,000 from 2.66 million to 2.81 million)". More people working in tourism, in whatever capacity, raises the significance of the sector in political, economic and social terms at a local and national level. As a consequence, it places key issues relating to tourism employment, such as working conditions and remuneration levels, in greater public focus.

\section{Baum's 2007 perspective}

Baum's 2007 paper provided a thematic analysis of key issues within the tourism workplace environment. At this stage, it is of value to reprise these themes and assess them in terms of their 2014 currency and changes that may have emerged within their domains. Table 3 provides a 
summary of the themes addressed in 2007 and highlights key areas where, perhaps, some change in emphasis may be detected.

\begin{tabular}{|c|c|}
\hline 2007 theme & Assessment of possible changes, 2007-2014 \\
\hline An assessment of tourism work, past and present & $\begin{array}{l}\text { There are clear indicators that the nature of work } \\
\text { continues to evolve in all sub-sectors of tourism - see, for } \\
\text { example, Baum's (2012) analysis of the changing work } \\
\text { environment of the airline sector. Alongside this is a } \\
\text { process whereby tourism work may be reconceptualised, } \\
\text { in many countries, from the simple to the complex, in part } \\
\text { by the incorporation of new or expanded areas, such as } \\
\text { technological distribution, wellness (Baum and } \\
\text { Lockstone-Binney, 2013) or security (Ball et al, 2014). } \\
\text { The status of tourism work may also have shifted } \\
\text { somewhat in response to changing economic conditions so } \\
\text { that potential entrants to the industry may be rather better } \\
\text { qualified than in the past and have commensurately higher } \\
\text { (and maybe unrealistic) expectations of what the } \\
\text { workplace can offer. }\end{array}$ \\
\hline $\begin{array}{l}\text { An assessment of the role of people/ human resources in } \\
\text { tourism }\end{array}$ & $\begin{array}{l}\text { People are frequently claimed to be a company's most } \\
\text { valuable asset and a number of tourism organisations } \\
\text { assert this commitment in stating their values and mission } \\
\text { (Solnet et al, 2013). The reality is, frequently, that } \\
\text { organisations do not live up to such lofty aspirations and } \\
\text { little appears to have changed in this regard over the past } \\
\text { seven years. At the same time, Enz (2009) shows clearly } \\
\text { that concerns about people resourcing are recognised as } \\
\text { the most pressing issues in the eyes of managers in the } \\
\text { industry. Factored into a current assessment of this theme } \\
\text { is clear evidence of changing expectations of work, } \\
\text { particularly among young people, bringing with it } \\
\text { significant impacts upon employer - employee relations in } \\
\text { the tourism industry of many countries (Solnet et al, } \\
\text { 2012). }\end{array}$ \\
\hline Globalisation and the tourism workforce & $\begin{array}{l}\text { Deloitte (2014:2) link generational change to globalisation } \\
\text { when they argue for the universality of new entrants to the } \\
\text { workforce. They note that "the } 21 \text { st-century workforce is } \\
\text { global, highly connected, technology-savvy, and } \\
\text { demanding. Its employees are youthful, ambitious, and } \\
\text { filled with passion and purpose. Millennials are a major } \\
\text { force-but so are older workers, who remain engaged and } \\
\text { valuable contributors. Critical new skills are scarce-and } \\
\text { their uneven distribution around the world is forcing } \\
\text { companies to develop innovative new ways to find people, } \\
\text { develop capabilities, and share expertise". These include } \\
\text { the extensive use of social media as a core recruitment } \\
\text { tool. Some of these factors, in turn, drive workforce } \\
\text { mobility in tourism and account for elements of labour } \\
\text { migration growth within the sector (Duncan et al, 2013). }\end{array}$ \\
\hline Impact of technology on tourism work & $\begin{array}{l}\text { Technology continues to play a major role in driving } \\
\text { workplace change in tourism, particularly through the use } \\
\text { of social media as a tool to organise and engage with a } \\
\text { wide range of e-HRM activities (Stroehmeier, 2007; } \\
\text { Parry, 2011), creating both positive impacts (faster } \\
\text { communications, virtual project teams) and negartive }\end{array}$ \\
\hline
\end{tabular}




\begin{tabular}{|c|c|}
\hline & $\begin{array}{l}\text { outcomes (depersonalising aspects of HRM). Marler } \\
\text { (2009) argues that the main driver for this development is } \\
\text { organisational self-interest, as a means of reducing cost } \\
\text { rather than acting strategically within a changing (and } \\
\text { global) labour market. Employees are also increasingly } \\
\text { impacted, in both positive and negative ways, by reviews } \\
\text { that may influence both future customers and employers } \\
\text { through travel review sites such as Trip Advisor. }\end{array}$ \\
\hline Skills bundling beyond the technical & $\begin{array}{l}\text { The inexorable move away from a focus on technical } \\
\text { skills in many areas of tourism to a wide interpretation of } \\
\text { employability attributes has continued. As Nijssen and } \\
\text { Paauwe (2012:3322) note in their discussion of athletic } \\
\text { labour, "Only if employees have a broad skill set, they can } \\
\text { perform a flexible range of tasks. To enhance this skill set, } \\
\text { training is vital. Specific forms of training in agile } \\
\text { organizations refer to cross-training and job-rotation". } \\
\text { Warhurst and Nickson (2007) note the increasing presence } \\
\text { of employee aesthetics in product and brand marketing } \\
\text { and the consequent pressure to use aesthetic criteria, } \\
\text { linked to brand, in selecting employees, often in a way } \\
\text { which discriminates. At the same time, in the specific } \\
\text { context of the airline industry, Curley and Royle } \\
\text { (2013:109) point to a decline in a service focus as time to } \\
\text { deliver the "repertoire of facial, bodily and verbal } \\
\text { expressions, for example using a low voice and } \\
\text { maintaining an amenable eye contact with passengers" is } \\
\text { reduced. }\end{array}$ \\
\hline Diversity in the workplace & $\begin{array}{l}\text { Tourism remains an industry that accommodates } \\
\text { employees from a diversity of backgrounds but } \\
\text { demographic change and the accelerating pace of both } \\
\text { domestic and international migration, particularly in } \\
\text { Europe and North America, mean that the complexion of } \\
\text { diversity in many countries has altered since 2007. The } \\
\text { changing age profile of the workforce inmdeveloped } \\
\text { countries such as Japan and Italy (Baum, 2010) means that } \\
\text { employers and other stakeholders need to have cognizance } \\
\text { of generational diversity in terms of, for example, shifts in } \\
\text { required skill sets and workplace expectations. There is } \\
\text { the need to develop the skills required to meet the needs of } \\
\text { an aging customer base. Continued mobility and migration } \\
\text { likewise have contributed to increasing diversity within } \\
\text { the tourism workforce. Tourism has also come under } \\
\text { increasing gaze in terms of achieving greater gender } \\
\text { balance, particularly in ghettoized work areas such as } \\
\text { restaurant kitchens as well as at senior management and } \\
\text { leadership levels (Baum, } 2013 \text { ). Baum (2013:78) notes } \\
\text { that "The extent and form of female employment in } \\
\text { tourism is strongly influenced by cultural, social, religious } \\
\text { and political factors. These considerations, together with } \\
\text { demographic and wider economic concerns, drive the } \\
\text { considerable variation that exists with respect to the } \\
\text { quantity and quality of female employment within } \\
\text { tourism." } \\
\text { However, there is also evidence of a backlash against } \\
\text { some dimensions of workplace diversity, particularly that }\end{array}$ \\
\hline
\end{tabular}




\begin{tabular}{|c|c|}
\hline & $\begin{array}{l}\text { induced by temporary or permanent migration. This is } \\
\text { evidenced by political debate in, among other locations, } \\
\text { Australia, Europe, Singapore and the United States and } \\
\text { could have significant consequences for the industry in } \\
\text { filling low-skills vacancies in key areas such as } \\
\text { housekeeping as well as the dispersal of migrants to } \\
\text { regional areas to meet employment gaps in the tourism } \\
\text { sector. It is also stimulating specific moves to reduce } \\
\text { dependence on foreign workers in the Gulf states through } \\
\text { the implementation of workforce indigenization policies } \\
\text { in a number of countries in the region (Mashood et al, } \\
\text { 2009). }\end{array}$ \\
\hline We're all one family....... & $\begin{array}{l}\text { In 2007, Baum argued that the reduction in social distance } \\
\text { between those who consume in tourism and those } \\
\text { employed by the sector in developed had significant } \\
\text { implications for workplace relations. This is further } \\
\text { compounded by both emotional and aesthetic dimensions } \\
\text { of the tourism workforce. This process is fueled by } \\
\text { generational change and career expectations (Maxwell et } \\
\text { al, 2010) and remains an important feature of work in } \\
\text { some sectors of contemporary tourism. In turn, this } \\
\text { highlights role ambiguity through the notion of partial } \\
\text { customers and partial employees in sectors such as bars } \\
\text { (Manolis et al, 2001; Sandiford and Seymour, 2013). } \\
\text { Customers can be seen as partial employees when } \\
\text { participating in service delivery (e.g. collecting and } \\
\text { clearing food in a fast food restaurant), while employees } \\
\text { are partial consumers when engaging in "the production } \\
\text { and consumption of the service as a symbolic act that } \\
\text { includes the production of themselves" (Manolis et al., } \\
\text { 2001: } 226 \text { ). At the same time, there is evidence that in } \\
\text { some work areas, notably airlines, there is a move to } \\
\text { reduce emotional and aesthetic engagement by employees } \\
\text { (Curley and Royle, } 2013 \text { ), particularly in low cost carriers, } \\
\text { thus challenging the notion of decreasing social distance. } \\
\text { However, in an emerging economy context, Lee } \\
\text { et al (2014:1) highlight the increasingly } \\
\text { structural nature of social distance within the } \\
\text { tourism economy when they refer to "the } \\
\text { precarious condition of labour in this fast } \\
\text { growing service sector of the world economy } \\
\text { and in so doing also adds much needed } \\
\text { empirical insights from the South to recent } \\
\text { debates about an emerging precariat in } \\
\text { contemporary capitalism". }\end{array}$ \\
\hline
\end{tabular}

Table 3: A brief retrospect - what has changed, 2007-2015

Table 3 recognises both subtle and fairly significant changes in the way that key themes identified by Baum in 2007 have continued to evolve. All remain of significance today and are referenceworthy in any consideration of the tourism workforce. However, in revisiting the theme of 
continuity and change in tourism work today, it is important to recognise the emergence of further themes that merit analysis.

\section{Emerging themes in Tourism HRM, 2015}

Baum's 2007 agenda was selective and made no claim to be comprehensive. The analysis in Table 3 points to the continuing significance of the issues that he identified at that time and highlights their further evolution. Interestingly, none of the issues covered has faded to a level of limited or no significance. However, taking analysis beyond the agenda identified in 2007, further systematic and comprehensive review of the extant literature leads to the identification of further, emergent themes that merit inclusion in this reflection on the state of HRM in tourism. As with the previous list (Table 3), the choice of these themes is, inevitably, selective but, collectively, the combined outcome of the 2007 and 2015 analyses provide a strong basis from which to extrapolate a meaningful picture of work in the global tourism industry.

\section{Contested (westernized) theory}

Management theories, especially those in the area of HRM, are predominantly Western-centric in origin and in the empirical testing that underpins them. There is increasing and critical challenge to analysis of theory that does not acknowledge the influence of culture. Lloyd and Payne (2013:3-4) underpin this debate in highlighting divergence across Europe with respect to interpretations of work organization, contrasting the high levels of autonomy and learning which characterize Scandinavia with the far more 'Taylorist' culture found in the UK. Likewise, Dickson et al (2012) recognise that leadership means different things across cultural contexts. Allied to this, and by way of illustration of the need to reconceptualise thinking about management theory in a cultural context, is research evidence on employee empowerment in tourism by Cheung et al (2012). They note the preponderance of Western-centric literature in the field of empowerment and question its applicability beyond a developed country context. With specific reference to an empirical study conducted in China, Cheung et al (2012:39) note that "Empowerment is in the center of the web but the influences of empowerment practices in China can be individual — as well as family- based. Individual-based influences are employees' virtue, skills and competency. Family or in-group based influences are family relationships between the managers and employees, trusting relationships and 
commitment from the managers." Similar challenges to westernised application of concepts like empowerment in other cultures in Asia and the Middle East highlight the need for far more localised interpretation of management theory so that organisations need to explre the transferability of management theory across cultural boundaries, particularly when considering how multinational tourism companies can effectively work with and manage their global employees.

\section{Blurring of tourism and related skills area roles}

Work in tourism, historically conceptualized as discreet and inward looking, is increasingly located within far more porous occupational boundaries, whereby the skills that are relevant within tourism have currency in other employment areas. At the same time, tourism increasingly calls upon skills traditionally associated with other areas of employment. By way of illustration of a trend that is becoming increasingly significant, Baum and Lockstone-Binney (2013) address the challenges of locating wellness tourism work alongside, on the one hand, related areas of tourism such as sports tourism, adventure tourism and cultural tourism and, on the other, the blurred boundaries between the skills required in wellness businesses and those which relate beyond tourism such as medical, fitness, religious and erotic/ sexual areas. This heterogeneity creates human resource challenges in terms of ethical and professional boundaries; training and qualifications; culture and diversity; as well as health and safety.

\section{Blurring of managerial and operational roles}

There is continued evidence for ongoing organisational delayering or lean management (Handel, 2014) within tourism businesses in developed countries and within multi-national organisations. This is driven by pressure on costs that focus attention on the need to reduce the levels and numbers of management within many organisations. However, alongside this trend has been recognition of the value of an engaged and committed workforce, empowered to make and take decisions at the front-line without reference to the supervisory and managerial hierarchy. This process has extended organisationally into the execution of the HRM function (Gollan et al, 2014), elaborated, in the context of tourism, by Solnet et al (2013:14) when they argue that "the operational manager, trained to cope with dimensions of internally focused individual and team management within a broadly organizational behavior brief (motivation, inter-team relationships, role allocation, and responsibility) has been catapulted into a role that is externally facing and has clear strategic implications in its execution (mediating the impact of external labor market changes, labor cost budgeting, recruitment, and development)." Thus, the blurring of managerial and operational roles 
in tourism, so characteristic of small businesses in the sector, continues to take hold as normal practice with larger organisations.

\section{Lifestyle employment choices}

Recognising the need for reciprocity is increasingly informing debates about work-life balance, workplace flexibility and notions of lifestyle employment decision-making (Bolton and Houlihan, 2007). This theme draws on a range of influencers, including personal choice and motivation; organisational culture; careers and career management; and life interests beyond the workplace. Major global companies are giving particular consideration to a range of concerns which key employees may have about their non-work lives in order to ensure that they can work and develop to the optimum of their potential within the organisation (see, for example, Rosewarne, 2014, on corporate egg freezing on behalf of female employees). By contrast, within tourism, women's role is frequently seen to be an extension of their domestic responsibilities and there is little compromise to life choice considerations. Hunter Powell and Watson (2006:309) see the value of domestic skills in terms of conscious managerial practice when they argue that "Employers take advantage of the social and domestic skills acquired by women through gender role socialisation and hire women for jobs involving cleaning, serving on people and nurturing children”.

The nature of tourism work, of course, continues to mitigate against realistic balance between work and life in the eyes of many employers (Sandiford and Seymour, 2013). Location is another important consideration, acting both positively to attract employees to work in specific places (ski resorts, surf beaches) or acting as a barrier to their attractiveness. Fotheringham et al (2000), indeed, highlight the importance of place attractiveness for those migrants who do have choice about where they locate and the difficulties in persuading people of work in peripheral regions in some countries (Tourism 2020 Labour and Skills Working Group, 2013).

\section{Urgent demand for leadership}

Tourism and, indeed, others sectors of the economy, are suffering from a leadership deficit as competition for scarce talent increases globally (Ross, 2013). Deloitte (2014:26) recognise that many organisations face a real challenge in developing future leaders at all levels and stress that "leadership remains the No. 1 talent issue facing organizations around the world". They continue by arguing that " 21 st-century leadership is different. Companies face new leadership challenges, including developing millennials and multiple generations of leaders, meeting the demand for 12 
leaders with global fluency and flexibility, building the ability to innovate and inspire others to perform, and acquiring new levels of understanding of rapidly changing technologies and new disciplines and fields". Tourism's ability to compete for leadership talent equipped across this range of areas is a challenge that is only slowly achieving recognition, meaning tourism is falling behind other, more proactive, sectors.

\section{Employers 1 Workers 0}

Arguably, the most significant shift in HRM in tourism since 2007 has been the shift in the balance of workplace power in favour of the employer. This may already have been the case in many developing countries because of the sheer size of labour market and the demand for work. However, in developed countries, a combination of cheap mobile labour, 'over-education' of the schoolleaving population, de-skilling technologies, a focus on cost cutting, higher unemployment created by collapse/contraction of other industries, especially among youth have all contributed to tipping the scales clearly in favour of employers and, in particular, larger businesses. As Thelen (2012:139) notes, there are compelling arguments which highlight that "employers everywhere inevitably seek to extend the reach of the market........ globalization and the attendant decline in organized labor's power and the resurgence of neoliberal ideology bode very ill for the future of the more egalitarian forms of capitalism”. There is little on the horizon that suggests a short-term reversal of this trend and this may have on-going consequences, perhaps negative, for the quality of work in tourism.

\section{Conclusions}

In 2007, Baum's review of human resource concerns within tourism concluded on a somewhat pessimistic and sombre note. Progress was identified, yes but, at the same time, clear evidence was forthcoming that change was slow at best and, in many countries and organisations, entirely stalled with respect to key areas such as working conditions, remuneration, the status of work, diversity management and workplace relations. It is difficult to reach more optimistic conclusions today. Indeed, a recent review of stakeholder assessments of workforce issues in tourism across two jurisdictions (Australia and Scotland) over a ten year timespan concluded that little progress had been made in traversing beyond the same, repetitious issues and the same, failed solutions (Solnet et al, 2014). 
Yet, at the same time, it is clear that work will continue to change, both in evolutionary and revolutionary state. Some aspects will continue to represent the progression of established trends but there will also, undoubtedly, be the influence of the yet unknown, whether shaped by sociocultural, political, economic, environmental or technological forces. Analyses of the future of work in tourism (for example, Solnet et al, 2013a; Robinson et al, 2013) operate, primarily along a known, trend-derived axis and, in a sense, this is inevitable. After all, it is unrealistic to expect stakeholders in tourism work to crystal-ball gaze beyond the world with which they are already familiar.

However, there is a growing argument that these stakeholders currently lack the vision to think beyond the here and now and, certainly, are not seriously planning for their future workforce needs. As a minimum, tourism businesses, facing future uncertainty, have an urgent need for organisational agility and flexibility (Dyer and Shafer, 1998). Dyer and Ericksen (2006:3) extend this notion to one of workforce scalability (or workforce fluidity - Nijssen and Paauwe, 2012) as a requirement for organizations operating in a dynamic environment. In their terms, workforce scalability refers to "the capacity of an organization to keep its human resources aligned with business needs by transitioning quickly and easily from one human resources configuration to another and another, ad infinitum."

Tourism work also needs to be considered in the growing employment futures narrative that focuses on knowledge or creative industries and both their economic and social significance. While this discourse is frequently located in an urban context (smart, future cities), it also emerges as a salvation for remote and peripheral regions. Tourism is also an important component in the economic make up of both major cities and rural bywaters. In this context, the focus of discussion highlights workforce themes (talent identification, development, rewards) in relation to employment within the knowledge, creative or innovative economies (see, for example, Thite, 2011; Vivant, 2013; Vanolo, 2014), building on Florida's (2002) conceptualisation of the creative class as the driver of future economic prosperity. There is a neglect of the alternative narrative (within which tourism is located) that recognises the role of what Hollands (2014) describes as "ordinary people" in the future economy, particularly from an employment perspective (Barresi and Pultrone, 2013). Tourism, seen substantively seen as a low skills sector, is not readily accommodated easily within the rhetoric of the smart city or economy and this manifestation of the dual labour market is likely to emerge as an increasingly important theme.

Star-gazing or attempting to guess the future of tourism has become a major industry, led by the work of Yeoman and others. In the tourism workforce futures domain, allusion has already been 
made to the contribution of Solnet et al (2013) and Robinson et al (2013). Equally important to these speculative forays into the future of tourism work is a focus on current-focused and on-going research into how trends in the macro PEST environment, in tourism and in the nature of work in contemporary societies, interact to create important change for stakeholders in tourism, in particular employers, employees and government. Such analysis should not be confined to periodic assessment but demands a continuous monitoring process and the sharing of outcomes with these stakeholder groups. With this process in place at a national but also a regional and global level, there should be no need to ask questions about workplace change in tourism again in 2021 . The answers should be readily available and accessible to all.

As a final reflection, work in tourism continues to change, certainly and some of the shifts over the past years, articulated in this paper, have been anything but subtle. But in other respects, some attributes of tourism work remain a stubborn stain on the reputation of the sector and continue to impact upon how we in the industry perceive ourselves as well as how others see us. Until there is tangible and sustainable evidence of real change in many of the fundamental areas highlighted in this paper, the waiting, however frustrating this experience may be, will have to continue. 


\section{References}

Addison, J. (2014), The consequences of trade union power erosion, IZA World of Labor, 68, doi: 10.15185/izawol.

Babu, S. (2014) Mass Customerisation: Next Generation Mass Customisation for Tourism, International Journal of Social Science and Management, 1(1), 115-119.

Ball, K., Canhoto, A., Daniel, E., Dibb, S., Meadows, M. and Spiller, K. (2014), Working on the Edge: remediation work in the UK travel sector, Work, Employment and Society, 28(2), 305-322.

Barresi, A. and Pultrone, G., European strategies for smarter cities, TeMA Journal of Land Use, Mobility and Environment 6(1), 61-72.

Baum, T. (2006) Human Resource Management for Tourism, Hospitality and Leisure. An International Perspective, London: International Thomson

Baum, T. (2007). Human resources in tourism: Still waiting for change, Tourism Management, 28(6), 1383-1399

Baum, T. (2010) "Demographic Changes and the Labour Market in the International Tourism Industry" in (eds) Yeoman, I., Hsu, C., Smith, K. and Watson, S., Tourism and Demography, Oxford: Goodfellow Publishers, 179-194.

Baum, T. (2012) "Working the skies: changing representations of gendered work in the airline industry, 1930 - 2011”, Tourism Management, 33(5), 1185-1194.

Baum, T. (2013), International Perspectives on Women and Work in Hotels, Catering and Tourism, Geneva: ILO

Baum, T. (2014), The changing profile of cabin crew: implications for passenger behaviour and the need for inter-cultural training, invited paper to DISPAX World, the $2^{\text {nd }}$ International Conference on Disruptive Airline Passenger Behaviour, London

Baum, T. and Lockstone-Binney, L. (2013), Fit for purpose: Delivering wellness tourism through people, in (eds) Pforr, C. and Voigt, C., Wellness Tourism: A Destination Perspective, London: Routledge, 130-143

Bolton, S., \& Houlihan, M. (2007). Beginning the search for the H in HRM. In S. Bolton, \& M. Houlihan (Eds.), Searching for the human in human resource management: theory, practice and workplace contexts, Basingstoke: Palgrave, 1-28.

Brinkley, I. (2013), Flexibility or insecurity? Exploring the rise in zero hours contracts, Lancaster: The Work Foundation.

Burns, J. (2014), Unpaid internships 'favour the rich', BBC, accessed at http://www.bbc.co.uk/news/education-29996607 on 17th November 2014. 
CAPA (2013), European airlines' labour productivity. Oxymoron for some, Vueling and Ryanair excel on costs, accessed at http://centreforaviation.com/analysis/european-airlines-labourproductivity-oxymoron-for-some-vueling-and-ryanair-excel-on-costs-97635, 15th February 2013

Cheung, C., Baum, T. and Wong, A. (2012), Relocating empowerment as a management concept for Asia, Journal of Business Research, 65(1), 36-41.

Clegg, S. (2014), Managerialism: Born in the USA, Academy of Management Review, 39(4), 566576.

COMCEC (2014), Enhancing the capacity of the tourism workforce in the OIC member countries for improved tourism service quality, Ankara: COMCEC Coordination Office

Cooper, C. (2014), New underemployment figures hint at the polarising effects of flexibility without balance, HR Magazine, $29^{\text {th }}$ October, accessed at http://www.hrmagazine.co.uk/hr/features/1147772/cary-cooper-

flexibility?utm content $=$ \&utm campaign $=\mathrm{HR} \% 20$ magazine $\% 20$ news $\% 2029 \% 20$ October $\% 202014$ \&utm source $=\mathrm{HR} \% 20 \mathrm{Magazine} \& u$ tm medium $=$ adestra email\&utm term $=\mathrm{http} \% 3 \mathrm{~A} \% 2 \mathrm{~F} \% 2 \mathrm{Fww}$ w.hrmagazine.co.uk\%2Fhr\%2Ffeatures $\% 2 \mathrm{~F} 1147772 \% 2 \mathrm{Fcary}$-cooperflexibility\#sthash.YKRpYDH8.dpuf on $29^{\text {th }}$ October 2014

Curley, C. and Royle, T. (2013), The degradation of work and the end of the skilled emotion worker at Aer Lingus: is it all trolley dollies now?, Work, Employment and Society, 27(1), 105-121

Davidson, M.C.G., McPhail, R., \& Barry, S. (2011). Hospitality HRM: Past, present and the future. International Journal of Contemporary Hospitality Management, 23(4), 498-516

Deloitte Consulting (2014), Global Human Capital Trends 2014. Engaging the $21^{\text {st }}$ Century Workforce, Deloitte University Press, accessed at http://d2mtr37y39tpbu.cloudfront.net/wpcontent/uploads/2014/03/GlobalHumanCapitalTrends_2014.pdf, $6^{\text {th }}$ October 2014

Dickson, M., Castano, N., Magomaeva, A. and Den Hartog, D. (2012), Conceptualizing leadership across cultures, Journal of World Business, 47(4), 483-492

Dowling, E. and Harvie, D. (2014), Harnessing the Social: State, Crisis and (Big) Society, Sociology, 48(5), 869-886

Duncan, T., Scott, D. and Baum, T. (2013), The mobilities of hospitality work: an exploration of issues and debates, Annals of Tourism Research, 41(4), 1-19.

Dyer, L., and Ericksen, J. (2006), Dynamic Organizations: Achieving Marketplace Agility Through Workforce Scalability, CAHRS Working Paper, 06-12.

Dyer, L., and Shafer, R. (1998), From Human Resource Strategy to Organizational Effectiveness: Lessons From Research on Organizational Agility, in (eds) Wright, P., Dyer, L., Boudreau, J. and Milkovich, G. Strategic Human Resource Management in the 21st Century: Research in Personnel and Human Resource Management, Supplement 4, , Stamford, CT: JAI Press, 145-174.

Edgell, D. (2014), Ten Tourism Trends for 2014 accessed at http://www.gwutourism.org/blog/tentourism-trends-for-2014/ on January $15^{\text {th }} 2015$.

Enz, C. (2009), Human resource management. A troubling issue for the global hotel industry, Cornell Hospitality Quarterly, 50(4), 578-583. 
Falcıoglu, P. (2014), The New Labor Skills in the New Economy, in (eds), Dereli, T., SoykutSarica, Y.P. and Şen-Taşbaşi, A. Labor and Employment Relations in a Globalized World Contributions to Economics, Berlin: Springer, 195-205.

Felstead, A., Green, F. and Jewson, N. (2012), An analysis of the impact of the 2008-9 recession on the provision of training in the UK, Work, Employment and Society, 26(6), 968-986.

Florida, R. (2002), The rise of the creative class: and how it's transforming work, leisure, community and everyday life, Basic Books.

Fotheringham, S., Champion, T., Wymer, C. and Coombes, M. (2000), Measuring destination attractivity: A migration example, International Journal of Population Geography, 6(6), 391-421

Gallie, D. (2007) Production regimes and the quality of employment in Europe. Annual Review of Sociology 33, 85-104

Gialis, S. and Leontidou, L. (2014), Antinomies of flexibilization and atypical employment in Mediterranean Europe: Greek, Italian and Spanish regions during the crisis, European urban and Regional Studies, DOI: 10.1177/0969776414538983.

Gollan, P., Kalfa, S. and Xu, Y. (2014), Strategic HRM and devolving HR to the line: Cochlear during the shift to lean manufacturing, Asia Pacific Journal of Human Resource Management, doi:10.1111/1744-7941.12055.

Haar, J., Russo, M., Suñe, A. and Ollier-Malaterre, A. (2014), Outcomes of work-life balance on job satisfaction, life satisfaction and mental health: A study across seven cultures, Journal of Vocational Behavior, 85(3), 361-373.

Hackett, L., Shutt, L.and Maclachlan, N. (2012) The way we'll work: Labour market trends and preparing for the Hourglass, London: University Alliance.

Handel, M. (2014), Theories of lean management: an empirical evaluation, Social Science Research, 44, 86-102.

Hollands, R. (2014), Critical interventions into the corporate smart city, Journal of Regions, Economy and Society, doi: 10.1093/cjres/rsu011.

Holm, J., Lorenz, E., Lundvall, B. and Valeyre, A. (2010) Organizational learning and systems of labor market regulation in Europe. Industrial and Corporate Change 19(4), 1141-73

Hunter Powell, P. and Watson, D. (2006), Service unseen: The hotel room attendant at work, International Journal of Hospitality Management, 25(2), 297-312

International Labour Office (ILO) (2010), Developments and challenges in the hospitality and tourism sector, Issues paper for discussion at the Global Dialogue Forum for the Hotels, Catering, Tourism Sector (23-24 November 2010), Geneva:ILO

Lee, D., Hampton, H. and Jeyacheya, J. (2014): The political economy of precarious work in the tourism industry in small island developing states, Review of International Political Economy, DOI: 10.1080/09692290.2014.887590. 
Lloyd, C. and Payne, J. (2013), Changing job roles in the Norwegian and UK fitness industry: in search of national institutional effects, Work, Employment and Society, 27(1), 3-20.

Kayode, O. (2012), Impact of Globalization on Human Resource Management, Science Journal of Business Management, 3, doi: 10.7237/sjbm/219

Kisby, B. (2010), The Big Society. Power to the People?, The Political Quarterly, 81(4), 484-491.

Kusluvan, S., Kusluvan, Z., Ilhan, I., \& Buyruk, L. (2010). The human dimension: a review of human resource management issues in the tourism and hospitality industry. Cornell Hospitality Quarterly, 51(2), 171-214.

Ladkin, A. (2011), Exploring Tourism Labor, Annals of Tourism Research, 38(3), 1135-1155.

Lee, D., Hampton, M and Jeyacheya, J. (2014), The political economy of precarious work in the tourism industry of small island developing states, Review of International Political Economy, DOI: 10.1080/09692290.2014.887590.

Lucas, R., \& Deery, M. (2004). Significant developments and emerging issues in human resource management. International Journal of Hospitality Management, 23(5), 459-472.

Manolis, C., Meamber, L., Winsor, R. and Brooks, C. (2001), Partial employees and consumers: a postmodern, meta-theoretical perspective for services marketing. Marketing Theory 1(2), 225-43.

Marler, J. (2009), Making human resources strategic by going to the Net: reality or myth?, The International Journal of Human Resource Management, 20(3), 515-527

Mashood, N., Verhoeven, H.and Chansarkar, B. (2009) Emiratisation, Omanisation, Saudisation: Common Causes: Common Solutions? in Proceedings of the 10th International Business Research Conference, Dubai

Maxwell, G., Ogden, S. and Broadbridge, A. (2010), Generation Y's Career Expectations and Aspirations: Engagement in the Hospitality Industry, Journal of Hospitality and Tourism Management, 17(1), 53-61

Mistilis, N., Buhalis, D. and Gretzel, U. (2014), Future eDestination Marketing: Perspective of an Australian Tourism Stakeholder Network, Journal of Travel Research, 53 (6), 778-790.

Nijssen, M. and Paauwe, J. (2012), HRM in turbulent times: how to achieve organizational agility?, The International Journal of Human Resource Management, 23(16), 3315-3335

Ockenden, N., Hill, M. and Stuart, J. (2012), The Big Society and Volunteering: ambitions and expectations, in (eds) Ishkanian, A. and Szreter, S. The Big Society Debate: A New Agenda for Social Welfare?, Cheltenham: Edward Elgar, 149-157.

Parry, E. (2011), An examination of e-HRM as a means to increase the value of the HR function, The International Journal of Human Resource Management, 22(5), 1146-1162.

Pastore, F. (2014), The Youth Experience Gap, Berlin: Springer. 
Payne, C. and White, S. (2014), Employment in Tourism Industries, London: Office of National Statistics.

Richter, L. (2001), Tourism Challenges in Developing Nations: Continuity and change at the Millenium, in (ed) Harrison, D., Tourism and the Less Developed World: Issues and Case Studies, Oxford: CABI, 47-59

Robinson, R., Ritchie, B.W., Kralj, A., Solnet, D., Baum, T. and Ford, R. (2013), An Asia-Pacific Core-Periphery Futures Paradox: Divergent Worker and Tourist Mobilities, Journal of Travel Research, DOI 0047287513513164.

Rosewarne, L. (2014), is corporate egg freezing such a rotten idea?, The Drum, accessed at http://www.abc.net.au/news/2014-10-15/rosewarne-is-corporate-egg-freezing-such-a-rottenidea/5815686 on 31 st October 2014

Ross, S. (2013), How definitions of talent suppress talent management, Industrial and Commercial Training, $45(3), 166$ $-170$

Sandiford, P. and Seymour, D. (2013), Serving and consuming: drink, work and leisure in public houses, Work, Employment and Society, 27(1), 122-137

Singh, N. Hu, C., and Roehl, W.S. (2007). Text mining a decade of progress in hospitality human resource management research: Identifying emerging thematic development. International Journal of Hospitality Management, 26(1), 131-147

Solnet, D., Kralj, A. and Kandampully, J. (2012), Generation Y employees: An examination of work attitude differences, Journal of Applied Management and Entrepreneurship, 17(3), 36-54.

Solnet, D., Kralj, A. and Baum, T. (2013), 360 degrees of pressure: The changing role of the HR Professional in the Hospitality Industry, Journal of Hospitality and Tourism Research, published online 2 January 2013 DOI: 10.1177/1096348012471380.

Solnet, D., Baum, T., Kralj, A., Robinson, R., Ritchie, B.W., Olsen, M. (2013a), The Asia-Pacific Tourism Workforce of the Future: Using Delphi Techniques to Identify Possible Scenarios, Journal of Travel Research, DOI: 10.1177/0047287513513163

Solnet, D., Nickson, D., Robinson, R., Kralj, A. and Baum, T. (2014 forthcoming), Discourse about workforce development in tourism - an analysis of public policy, planning and implementation in Australia and Scotland: hot air or making a difference?, Tourism Analysis.

Stroehmeier, S. (2007), Research in e-HRM: Review and Implications, Human Resource Management Review, 17(1), 19-37.

Thelen, K. (2012), Trajectories of Liberalization and the New Politics of Social Solidarity, Annual Review of Political Science, 15, 137-59.

Thite, M (2011), Smart cities: Implications of urban planning for human resource development, Human Resource Development International, 14(5), 623-632. 
Tourism 2020 Labour and Skills Working Group (2013), The Red Centre Tourism Employment Plan, Canberra: Department of resources, Energy and Tourism

Tracey, B. (2014), A review of human resources management research, International Journal of Contemporary Hospitality Management, 26(5), 679 - 705

Vanolo, A. (2014), Smartmentality: The Smart City as Disciplinary Strate, Urban Studies, 51(5), 883-898.

Vivant, E. (2013), Creatives in the city: urban contradictions of the creative city, City, Culture and Society, 4(2), 57-63.

Warhurst, C. and Nickson, D. (2007), Employee experience of aesthetic labour in retail and hospitality, Work, Employment and Society, 21(1), 103-120.

Willcocks, L., (2011) Machiavelli, management and outsourcing: still on the learning curve, Strategic Outsourcing: An International Journal, 4(1), 5 - 12.

World Travel and Tourism Council (2014), Travel and Tourism Economic Impact 2014: World, London: WTTC

Xiang, Z., Magnini, V. and Fesenmaier, D. (2015), Information technology and consumer behavior in travel and tourism: insights from travel planning using the internet, Journal of Retailing and Consumer Services, 22(1), 244-249

Zagelmeyer, S. \& Gollan, P. (2012): Exploring terra incognita: preliminary reflections on the impact of the global financial crisis upon human resource management, The International Journal of Human Resource Management, 23(16), 3287-3294. 